\title{
Diversity and prevalence of entomopathogenic fungi (Ascomycota, Hypocreales) in epidemic populations of bark beetles (Coleoptera, Scolytinae) in spruce forests of the Tatra National Park in Slovakia
}

\author{
Silvia Hyblerová', Juraj Medo², Marek Barta ${ }^{3 \varpi}$
}

Hyblerová S., Medo J., Barta M., 2021. Diversity and prevalence of entomopathogenic fungi (Ascomycota, Hypocreales) in epidemic populations of bark beetles (Coleoptera, Scolytinae) in spruce forests of the Tatra National Park in Slovakia. Ann. For. Res. 64(1): 129-145.

Abstract Bark beetles are serious forest pests in Slovakia. Their outbreaks may have significant ecological and economic impacts on spruce forests. There is a variety of natural enemies that activate themselves during population outbreaks of insects and entomopathogenic fungi belong to important antagonists with a potential to regulate populations of their hosts. In 2014-2016, species richness and prevalence of entomopathogenic fungi were evaluated during the bark beetle outbreaks in spruce forests affected by windstorms in the Tatra National Park in Slovakia. Three Beauveria species, B. bassiana, B. caledonica and B. pseudobassiana, with Metapochonia bulbillosa were identified from 271 specimens of three bark beetle species, Ips typographus, Ips amitinus and Pityogenes chalcographus. Beauveria bassiana was the dominant pathogen and infected all three bark beetle species. Phylogenetic analysis identified three phylogenetic groups of $B$. bassiana in the evaluated host populations. M. bulbillosa was reported for the first time from bark beetle hosts and Slovakia. The prevalence of fungal infection in natural populations of I. typographus was low, varied between 0.07 and $0.72 \%$, and have little influence on the bark beetle abundance.

Keywords: bark beetle outbreaks, Beauveria, Metapochonia, Picea abies, Slovakia.

Addresses: ${ }^{1}$ Research Station of State Forests of TANAP, Tatranská Lomnica, Slovakia| ${ }^{2}$ Department of Microbiology, Faculty of Biotechnology and Food Sciences, Slovak University of Agriculture in Nitra, Slovakia| ${ }^{3}$ Institute of Forest Ecology, Slovak Academy of Sciences, Nitra, Slovakia.

Corresponding Author: Marek Barta (marek.barta@savba.sk).

Manuscript received February 25, 2021; revised June 15, 2021; accepted June 15, 2021. 


\section{Introduction}

Norway spruce, Picea abies L. H. Karst., is one of the most common and economically most important tree species in Central Europe. In Slovakia, spruce forests cover, mostly in monocultures, 22\% (approximately 430000 ha) of the total forest area. Recently, these forest ecosystems have been confronted with severe destabilisation in Central Europe due to various disturbance agents (Nopp \& Führer 2000) and outbreaks of insect pests belong among the most important biotic disturbance factors. Bark beetles (Coleoptera, Scolytinae) are a specific group of insect pests having significant ecological and economic impacts on forest ecosystems (Grégoire \& Evans 2007). This relatively large group of insects is represented approximately by 220 genera with 6000 species worldwide (Knížek \& Beaver 2007), but only few of them pose a serious threat to Norway spruce in Europe. The European spruce bark beetle, Ips typographus L., is the most important species of this group (Grodzki et al. 2004, Wermelinger 2004, Økland et al. 2016). It is mainly damaging to mature spruce stands. Pityogenes chalcographus L., Ips amitinus Eichhoff, Ips duplicatus Sahlberg and Polygraphus poligraphus L. are also common bark beetle species attacking spruce stands, but their eruptive potential is less prominent. Pityogenes chalcographus prefers to colonise young (10-20 years old) or middle aged (2040 years old) spruce forests. Ips amitinus often occurs together with I. typographus at higher elevations and spruce stands in lower elevations are frequently infested by $I$. duplicatus. Polygraphus poligraphus attacks older spruce forests stressed by air pollution and weakened by root fungal infections (Turčáni \& Hlásny 2007, Grodzki et al. 2010). Ips typographus, the most destructive pest of spruce forests in Eurasia, attacks damaged, physiologically stressed, and dying trees. However, it can also colonise healthy trees and may act as primary mortality agent of spruce trees if the population density exceeds critical levels (Wermelinger 2004). In Europe, outbreaks of I. typographus have intensified significantly during the past two decades and they were usually triggered by wind disturbances and climatic drivers (e.g. Økland \& Bjørnstad 2006, Kautz et al. 2011, Vakula et al. 2013, Stadelmann et al. 2014, Seidl et al. 2015, Økland et al. 2015, 2016, Jakoby et al. 2019, Hlásny et al. 2021). The current massive outbreaks of bark beetles in Slovakia were activated by 'Alžbeta' windstorm that struck the northern areas of Slovakia in November 2004 (Kunca \& Zúbrik 2006, Vakula et al. 2013, Ferenčík 2016). The spruce stands in the Tatra National Park were the most damaged and about 30\% (12 500 ha) of the total forest cover was affected in the park (Falt'an et al. 2011, Ferenčík 2016). Due to pest management restrictions in this reserve area, the damaged wood could not be processed and became attractive to bark beetles. Subsequent outbreaks destroyed nearly $20 \quad 000$ ha of spruce forests that was a half of the park area (Fleischer et al. 2016). The ongoing bark beetle outbreaks have developed into the largest and most severe calamity in Slovakia and the total damage to timber due to the bark beetle outbreaks has already exceeded the damage caused by the windstorm (Vakula et al. 2013).

A combination of phytosanitary measures, insecticide treatments and pheromone trappings are usually applied to control bark beetle populations in spruce forests (Wermelinger 2004). However, specific problems arise in nature reserves where chemical control is not allowed and other measures are also limited. In such areas, biocontrol is under consideration as an alternative pest management strategy with the exploitation of different natural enemies, including entomopathogenic fungi (e.g. Landa et al. 2001, Hilszczański et al. 2007, Wegensteiner 2007, Wegensteiner et al. 2010, 2015a, 2015b, Fora et al. 2014, Barta et al. 2018a, 2020). Limitations in successful use of entomopathogenic fungi against bark beetles arising from environmental conditions unique 
to bark beetle habitats have been recently reviewed and a framework for standardising and improving laboratory assays to enhance field applications has been provided (Mann \& Davis 2021). Entomopathogenic fungi (EPF) are insect parasites that participate in a natural regulation of host populations (Augustyniuk-Kram \& Kram 2012, Vega et al. 2012). Hypocrealean entomopathogenic fungi (Ascomycota, Hypocreales), acting as natural regulators of insect populations, are constantly present in bark beetle populations (e.g. Wegensteiner et al. 2015b, Barta et al. 2018a) and their activity usually increases with a culmination of host population density (Augustyniuk-Kram \& Kram 2012). A relatively broad range of EPF is known from bark beetles in Europe (e.g. Wegensteiner et al. 2015b) and Beauveria species were often recognised as the principal pathogens (e.g. Landa et al. 2001, Draganova et al. 2010, Wegensteiner et al. 2015a, Barta et al. 2018a, 2020). Many studies on entomopathogens of bark beetles have been targeted to $I$. typographus and there is only limited information on pathogens of other bark beetle species like I. duplicatus, Ips sexdentatus Börner or Dryocoetes autographus Ratzeburg (e.g. Draganova et al. 2010, Dinu et al. 2012, Wegensteiner et al. 2015a). In Slovakia, a species diversity of EPF in I. typographus has been recently studied, but special attention was put to the Beauveria genus and to a selection of highly virulent strains suitable for the bark beetle biocontrol (Barta et al. 2018a). In this study, we were interested in the activation of natural antagonists - entomopathogenic fungi - during the ongoing population outbreaks of bark beetles in Norway spruce forests of the Tatra National Park (Slovakia) affected by windstorms. We determined a species richness of hypocrealean EPF in communities of different bark beetle species and evaluated a prevalence of the fungi in I. typographus populations during its massive gradation.

\section{Materials and Methods}

\section{Study area}

The study was performed in the Tatra National Park (49.180278 N, 19.919444 E), the highaltitude region (600-2 $600 \mathrm{~m}$ a.s.1.) of the Tatra Mountains in north central Slovakia. The Tatra Mountains are the highest mountain range in the Carpathian Arch forming a natural border between Slovakia and Poland. The park was established in 1949 and currently extends over $738 \mathrm{~km} 2$, with $307 \mathrm{~km}^{2}$ of a protection zone. Forests cover an area of 50000 ha and create almost a continuous vegetation belt spreading from $700 \mathrm{~m}$ a.s.l. up to the timberline at 1550 $\mathrm{m}$ a.s.1. (Fleischer et al. 2005). The forests are dominated by $P$. abies with Larix decidua Mill., Pinus cembra L., and few broadleaved trees (beech, sycamore, birch, alder etc.) as admixture species. The climate in the area is cold and humid with the average annual air temperature of $5.8{ }^{\circ} \mathrm{C}$ and the average annual precipitation of $1100-1900 \mathrm{~mm}$. The mean duration of snow cover varies from 124 days at the base to 228-236 days at $2000 \mathrm{~m}$ a.s.l. The maximum thickness of snow cover occurs in February in the lower parts and in the second half of March at higher altitudes (Niedzwiedz 1992). In November 2004, heavy windstorm 'Alžbeta' struck the park and damaged more than five million cubic metres of Norway spruce. In the following years, bark beetle populations rapidly increased because practically no sanitation felling or salvage logging of fallen trees could be conducted due to the protection status of the affected areas. Ten years after the windstorm, 15 sites of uniform Norway spruce stands of age $>80$ years were selected in the damaged areas for evaluation of species diversity of entomopathogenic fungi in bark beetle populations (Figure 1). The population dynamics of the dominating bark beetle species I. typographus reached the outbreak phase (defined by Biedermann et al. 2019) during the sampling. The sites 
were selected with the purpose to be evenly distributed throughout the park and to reflect the existing foci of bark beetle outbreaks.

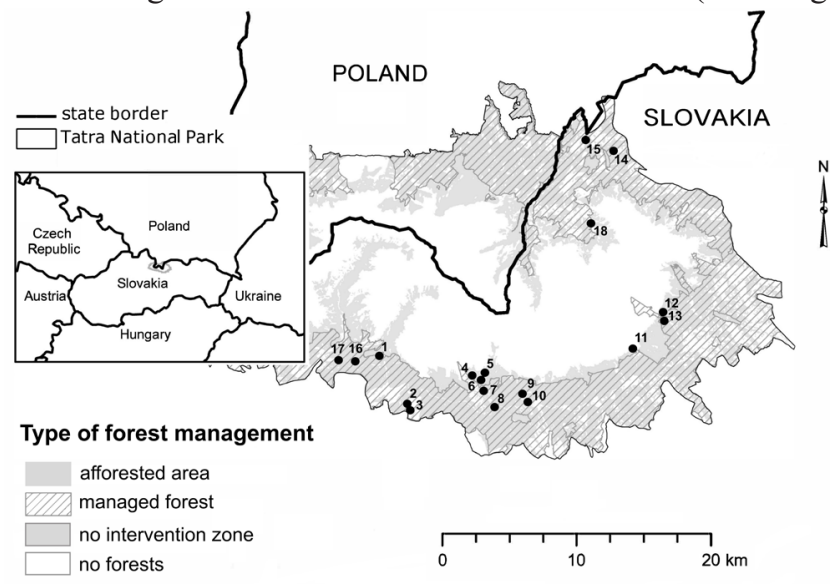

Figure 1 A map of the Tatra National Park showing sites $(\bullet)$ where species diversity and prevalence of entomopathogenic fungi in bark beetle populations were studied during 2014-2016.

\section{Bark beetle sampling and fungus isolation}

To determine a species richness of entomopathogenic fungi, fungus-infected bark beetles were collected in the park from July to September in 2014 and 2015. The specimens were collected from windthrown spruce trees that were naturally infested in the spring of the same year. Adult bark beetles with typical macroscopic symptoms of fungal infection were placed individually in sterile $2.0-\mathrm{ml}$ cryogenic vials. The specimens were screened for the presence of entomopathogenic fungi by a dissecting microscope $(50 \times)$ and individuals that had died from other factors were excluded from further analyses. Bark beetle species were identified according to the external morphology of adults and the architecture of gallery systems under the bark (Cognato 2015). Samples with confirmed fungal infection were used for isolation of axenic cultures. Axenic cultures were obtained by incubating individuals with fungal infection onto Sabouraud dextrose agar (SDA) plates supplemented with fungicides $(250 \mathrm{mg} / \mathrm{L}$ cycloheximide and $500 \mathrm{mg} / \mathrm{L}$ dodine) and antibiotics $(600 \mathrm{mg} / \mathrm{L}$ streptomycin sulphate, $50 \mathrm{mg} / \mathrm{L}$ tetracycline hydrochloride). The plates were incubated at $25 \pm 1{ }^{\circ} \mathrm{C}$ for 10 days and fungal colonies were transferred onto fresh SDA plates without fungicides and antibiotics. The obtained cultures were stored at $4{ }^{\circ} \mathrm{C}$.

\section{Identification of entomopathogenic fungi}

Axenic cultures were identified to a genus level by a microscopic $(500 \times)$ investigation of fungal microstructures (Rehner \& Buckley 2005, Rehner et al. 2011, Humber 2012). The morphological identification was coupled to the rDNA-ITS sequencing study. The DNA was extracted from the biomass of 10-dayold fungal cultures. Approximately $50 \mathrm{mg}$ of mycelium was put into a 2-ml microtube with $200 \mu \mathrm{l}$ of PrepManTM Ultra Sample Preparation Reagent (Life Technologies, USA) and homogenised with glass beads (diam. 2 $\mathrm{mm})$ by BeadBug Microtube Homogenizer (Benchmark scientific, USA) for $2 \mathrm{~min}$. After a 15 -min treatment at $110^{\circ} \mathrm{C}$ in thermoblock BioTDB 120 (Biosan, Latvia), the samples were centrifuged for $5 \mathrm{~min}$ at $24000 \times \mathrm{g}$. As many as $1 \mu \mathrm{l}$ of the resulting supernatant was used in the PCR reactions. The internal transcribed spacer (ITS) region of the nuclear DNA was amplified with the primer pairs ITS5/ITS4 (White et al. 1990). A PCR mixture $(30 \mu \mathrm{l})$ contained $3 \mu \mathrm{l}$ of $10 \mathrm{X}$ Dream Taq DNA buffer, $3 \mu 1$ of $2 \mathrm{mM}$ dNTP mix, $1 \mu \mathrm{l}$ of $25 \mathrm{mM} \mathrm{MgCl} 2,1.2 \mu \mathrm{l}$ of primers $(10 \mathrm{mM}), 1$ $\mu 1$ of bovine serum albumin $(25 \mathrm{mg} / \mathrm{ml}), 0.5$ $\mathrm{U}$ of Dream Taq DNA polymerase and $1 \mu \mathrm{l}$ of genomic DNA. The PCR amplification was 
performed in a thermocycler MJ Mini (Biorad, USA) under the following cycling conditions: $95^{\circ} \mathrm{C}$ for $60 \mathrm{~s}$ followed by 45 cycles of $95^{\circ} \mathrm{C}$ for $30 \mathrm{~s}$, annealing at temperature $56{ }^{\circ} \mathrm{C}$ for $30 \mathrm{~s}, 72{ }^{\circ} \mathrm{C}$ for $30 \mathrm{~s}$ and a final elongation at $72{ }^{\circ} \mathrm{C}$ for $5 \mathrm{~min}$. Amplification products were purified using exonuclease I and FastAP (Life Technologies, USA). Sequencing was performed by Macrogen Europe B.V. (Amsterdam, the Netherlands), sequences were deposited in the NCBI GenBank database and compared with data from the GenBank using the BLASTn algorithm for identification of fungi. The sequences from this study and the reference sequences of all currently available ex-type strains of Beauveria and Metapochonia in the GenBank (Table 1) were aligned using MUSCLE (Edgar 2004) and used for the phylogenetic analysis in MEGA X software (Kumar et al. 2018). A phylogenetic tree was constructed using the Maximum likelihood method (ML) with TN93 substitution model (Tamura \& Nei 1993), BioNJ starting tree with the best of NNI tree searching, and followed by 1000 bootstrap replications. Alignment gaps were treated as missing data.

Table 1 List of species of entomopathogenic fungi with ITS sequences retrieved from the NCBI GenBank database used in the phylogenetic analysis.

\begin{tabular}{|c|c|c|c|c|c|}
\hline Fungal species & $\begin{array}{l}\text { Strain } \\
\text { code }\end{array}$ & Locality & Host/Substrate & GenBank & References \\
\hline $\begin{array}{l}\text { Beauveria } \\
\text { amorpha }\end{array}$ & ARSEF 7542 & USA, Colorado & Hymenoptera: Formicidae & HQ880805 & Rehner et al. (2011) \\
\hline B. asiatica & ARSEF 4850 & South Korea, Chiag Mt. & Coleoptera: Cerambycidae & HQ880787 & Rehner et al. (2011) \\
\hline B. australis & ARSEF 4598 & Australia, Tasmania & Soil & HQ880789 & Rehner et al. (2011) \\
\hline B. baoshanensis & BUB283 & China, Gaoligong Mt. & Lepidoptera: Lymantridae & MG642828 & Chen et al. (2019) \\
\hline B. bassiana & ARSEF 1564 & Italy, Villa Cade & $\begin{array}{l}\text { Lepidoptera: Hyphantria } \\
\text { cunea }\end{array}$ & HQ880761 & Rehner et al. (2011) \\
\hline B. bassiana & ARSEF 1848 & Belgium & $\begin{array}{l}\text { Coleoptera: } \\
\text { Rhizophagidae }\end{array}$ & AY531995 & Rehner and Buckley (2005) \\
\hline B. bassiana & B78-5 & $\begin{array}{l}\text { Slovakia, Tatranská } \\
\text { Lomnica }\end{array}$ & Ips typographus & MW051928 & This study \\
\hline B. bassiana & B2110-1 & Slovakia, Podbanské & Pityogenes chalcographus & MW051979 & This study \\
\hline B. bassiana & A14-5 & $\begin{array}{l}\text { Slovakia, Tatranská } \\
\text { Lomnica }\end{array}$ & Ips typographus & MW051976 & This study \\
\hline B. bassiana & NREP100 & Slovakia & Hylobius abietis & MK490878 & Barta et al. (2019) \\
\hline B. bassiana & IK10 & Slovakia, Michalovo & Ips typographus & KY352660 & Barta et al. (2018) \\
\hline B. bassiana & MK167 & Slovakia, Lysá Pol'ana & Ips typographus & KY352659 & Barta et al. (2018) \\
\hline B. bassiana & BG21 & Bulgaria: Vitosha & Ips typographus & MT180396 & Barta et al. (2020) \\
\hline B. bassiana & SUAh03 & Slovakia & Soil & KJ489072 & Medo et al. (2016) \\
\hline B. bassiana & SUAo38 & Slovakia & Soil & KJ489065 & Medo et al. (2016) \\
\hline B. bassiana & SUAa46 & Slovakia & Soil & MT239412 & Medo et al. (2021) \\
\hline B. bassiana & SUAe81 & Slovakia & Soil & KJ489075 & Medo et al. (2016) \\
\hline B. brongniartii & $\mathrm{Je} 276$ & Switzerland & Coleoptera: Scarabaeidae & HQ880784 & Rehner et al. (2011) \\
\hline B. caledonica & ARSEF 2567 & Scotland & Soil & HQ880817 & Rehner et al. (2011) \\
\hline B. caledonica & Ab16-1 & Slovakia, Krivánska cesta & Ips typographus & MW052024 & This study \\
\hline B. caledonica & MK206 & Slovakia, Hnilčík & Ips typographus & KY352729 & Barta et al. (2018) \\
\hline B. hoplocheli & Bt96 & Madagascar & $\begin{array}{l}\text { Coleoptera: } \\
\text { Melolonthidae }\end{array}$ & KC339697 & $\begin{array}{l}\text { Robène-Soustrade et al. } \\
\text { (2015) }\end{array}$ \\
\hline B. kipukae & ARSEF 7032 & USA, Hawaii & Homoptera: Delphacidae & HQ880803 & Rehner et al. (2011) \\
\hline B. lii & RCEF5500 & China, Xianyang & Coleoptera: Coccinellidae & JN689372 & Zhang et al. (2012) \\
\hline
\end{tabular}


Table 1 List of species of entomopathogenic fungi with ITS sequences retrieved from the NCBI GenBank database used in the phylogenetic analysis.

\begin{tabular}{|c|c|c|c|c|c|}
\hline Fungal species & $\begin{array}{l}\text { Strain } \\
\text { code }\end{array}$ & Locality & Host/Substrate & GenBank & References \\
\hline B. majiangensis & GZU12141 & China, Guizhou: Majiang & Coleoptera: Scarabaeoidea & MG052643 & Chen et al. (2018) \\
\hline B. malawiensis & IMI 228343 & Malawi, Zomba & Coleoptera: Cerambycidae & DQ376247 & Rehner et al. (2006) \\
\hline B. medogensis & BUB426 & China, Gaoligong Mt. & Hymenoptera: Formicidae & MG642832 & Chen et al. (2019) \\
\hline B. pseudobassiana & ARSEF 3405 & USA, Virginia & Lepidoptera: Erebidae & HQ880792 & Rehner et al. (2011) \\
\hline B. pseudobassiana & B2710-13 & $\begin{array}{l}\text { Slovakia, Tatranská } \\
\text { Lomnica }\end{array}$ & Ips typographus & MW052021 & This study \\
\hline B. pseudobassiana & MK394 & Slovakia, Čierny Váh & Ips typographus & KY352725 & Barta et al. (2018) \\
\hline B. rudraprayagi & MTCC 8017 & India, Rudraprayag & Lepidoptera: Bombycidae & JQ266173 & Agrawal et al. (2014) \\
\hline B. scarabaeidicola & ARSEF 7281 & $\begin{array}{l}\text { South Korea: } \\
\text { Guryungryung }\end{array}$ & Coleoptera: Scarabaeidae & HQ880815 & Rehner et al. (2011) \\
\hline B. sinensis & RCEF3903 & China, Anhui & Lepidoptera: Geometridae & HQ270152 & Chen et al. (2013) \\
\hline B. varroae & ARSEF 8257 & France, Montdardier & Acari: Varroidae & HQ880800 & Rehner et al. (2011) \\
\hline B. vermiconia & ARSEF 2922 & Chile, Valdivia & Soil & HQ880822 & Rehner et al. (2011) \\
\hline B. acridophila & AV1875 & $\begin{array}{l}\text { Colombia, Zaphire } \\
\text { Reserve }\end{array}$ & Orthoptera: Proscopiidae & JQ958602 & Sanjuan et al. (2014) \\
\hline B. diapheromeriphila & MV2492 & $\begin{array}{l}\text { Ecuador, Jatunsacha } \\
\text { Reserve }\end{array}$ & $\begin{array}{l}\text { Phasmatodea: } \\
\text { Diapheromeridae }\end{array}$ & JQ958603 & Sanjuan et al. (2014) \\
\hline B. gryllotalpidicola & BCC26300 & $\begin{array}{l}\text { Thailand, Nakhon } \\
\text { Ratchasima }\end{array}$ & Orthoptera & FJ459787 & Ariyawansa et al. (2015) \\
\hline B. locustiphila & TS881 & Colombia, Tolima & Orthoptera: Romaleidae & JQ958606 & Sanjuan et al. (2014) \\
\hline B. loeiensis & BCC23104 & Thailand, Loei & Orthoptera & FJ459784 & Ariyawansa et al. (2015) \\
\hline $\begin{array}{l}\text { Metapochonia } \\
\text { bulbillosa }\end{array}$ & CBS 145.70 & Denmark & Roots of Picea abies & NR154142 & Zare et al. (2001) \\
\hline M. bulbillosa & B18-13 & Slovakia, Vyšné Hágy & Ips typographus & MW052028 & This study \\
\hline $\begin{array}{l}\text { Metarhizium } \\
\text { anisopliae }\end{array}$ & ARSEF 7487 & Eritrea & $\begin{array}{l}\text { Orthoptera: Schistocerca } \\
\text { gregaria }\end{array}$ & HQ331446 & Schneider et al. (2011) \\
\hline
\end{tabular}

\section{Prevalence of fungal infection in Ips typographus populations}

The prevalence of EPF was evaluated in populations of I. typographus that was the dominating and most destructive species in the Tatra National Park. For this purpose, spruce tree logs were collected at nine most affected sites (Table 2) during May-October 2016. At each sampling site, 3-15 logs (approximately $2 \mathrm{~m}$ long) of naturally infested trees were transferred to the laboratory. The circumference of the logs was measured at both ends and the average circumference was calculated for each 134 $\log$. The bark was stripped of the logs so that the size of debarked area had the length of $0.5 \mathrm{~m}$ and the width reached a half the circumference of the particular log. The total debarked area was calculated for each log. The effort was put to get the bark in a single piece from each $\log$ because it was used for the evaluation of infestation by bark beetles and prevalence of fungal infection. On each piece of bark, the total number of completely developed larval galleries and fungus-killed individuals was recorded. The dead insects were handled as mentioned above and used for fungal species identification. The infestation of logs by bark beetles was 
expressed as the number of larval galleries counted per area of one square metre.

Prevalence of infection in host populations was calculated using the formula:

$$
\text { infection prevalence }=\frac{N G I}{T N G} \times 100,
$$

where $N G I$ is number of galleries with infected individuals and $T N G$ is total number of galleries.

Table 2 List of sites in the Tatra National Park where prevalence of fungal infection was studied in bark beetles populations during May-October 2016.

\begin{tabular}{lccc}
\hline Name of collection site* $^{*}$ & Altitude(m) & Coordinates of site & No. of logs** $^{* *}$ \\
\hline Podbanské I (1) & 1131 & $49.144722^{\circ} \mathrm{N} ; 19.958611^{\circ} \mathrm{E}$ & 15 \\
Podbanské II (16) & 1168 & $49.141667^{\circ} \mathrm{N} ; 19.938889^{\circ} \mathrm{E}$ & 4 \\
Podbanské III (17) & 1140 & $49.142163^{\circ} \mathrm{N} ; 19.926575^{\circ} \mathrm{E}$ & 6 \\
Vyšné Hágy I (9) & 1133 & $49.125181^{\circ} \mathrm{N} ; 20.108297^{\circ} \mathrm{E}$ & 8 \\
Vyšné Hágy II (10) & 1128 & $49.118803^{\circ} \mathrm{N} ; 20.112651^{\circ} \mathrm{E}$ & 4 \\
Javorová dolina (18) & 1293 & $49.216925^{\circ} \mathrm{N} ; 20.159143^{\circ} \mathrm{E}$ & 10 \\
Podspády - Krupovky (14) & 908 & $49.285008^{\circ} \mathrm{N} ; 20.175114^{\circ} \mathrm{E}$ & 3 \\
Tatranská Lomnica I (12) & 857 & $49.073611^{\circ} \mathrm{N} ; 20.145000^{\circ} \mathrm{E}$ & 9 \\
Tatranská Lomnica II (13) & 1400 & $49.183861^{\circ} \mathrm{N} ; 20.245046^{\circ} \mathrm{E}$ & 11 \\
\hline
\end{tabular}

*Numbers in the parenthesis refer to the particular collection sites as displayed in Figure 1.

**Number of spruce tree logs collected for evaluation of fungal prevalence at a particular site.

\section{Data analysis}

The mean values of infection prevalence and infestation of logs by bark beetles per collection sites were tested for normality by the Kolmogorov-Smirnov test. Data for infestation were square-root transformed and data for infection prevalence were arscine transformed to get normally distributed data. The transformed data were subjected to ANOVA with the aim to compare infestation and infection prevalence means among the sites $(p=0.05)$. The post-hoc Tukey's HSD test was performed to separate and compare the means if significant differences $(p=0.05)$ were detected. Pearson correlation was performed to test the relationship between the infestation levels of spruce logs with bark beetles and the prevalence of fungal infection. All the analyses were conducted using Minitab 17® (C) 2013 Minitab Inc.).

\section{Results}

\section{Species spectrum of entomopathogenic fungi in bark beetle populations}

During the survey, 271 samples of dead bark beetles (205 samples of I. typographus, 18 samples of $I$. amitinus, 24 individuals of $P$. chalcographus) showing external symptoms of fungal infection were collected. As many as 24 dead beetles could not be identified to the species level and were excluded from the further analyses. Dead bark beetles with confirmed mycosis by microscopic observations were used for isolation of in vitro cultures on the agar plates. Axenic cultures were obtained from 171 dead beetles. The remaining samples produced no fungal colonies. From a single dead individual one axenic culture was always isolated. Altogether, 120 isolates were identified as entomopathogenic species by molecular analyses (Table 3). The amplicons of ITS region were deposited in the NCBI GenBank database under the accession numbers given in Table 4. The obtained sequences were compared with the GenBank database and three Beauveria species were identified, Beauveria bassiana (Bals.-Criv.) Vuill. (111 isolates), B. caledonica Bissett \& Widden (five isolates) and B. pseudobassiana S.A. Rehner \& R.A. Humber (two isolates). All sequences were supported by a high degree ( $>99 \%$ ) of identity with sequences of the neotype B. bassiana strain ARSEF 1564 and the type strains of $B$. caledonica (ARSEF 2567) or $B$. 
pseudobassiana (ARSEF 3405). Two fungal isolates were identified as Metapochonia bulbillosa (W. Gams \& Malla) Kepler, S.A. Rehner \& Humber. Beauveria bassiana as the dominant pathogen in the bark beetle populations was detected in 13 sites. The less frequent species $B$. caledonica and $B$. pseudobassiana were isolated from samples collected in just three or two sites, respectively. Metapochonia bulbillosa was observed in a single site. The EPF were isolated from three bark beetle species, I. typographus, I. amitinus and $P$. chalcographus, but not all pathogens were observed in each bark beetle species. While $B$. bassiana was isolated from all species, B. pseudobassiana and B. caledonica were not detected in $P$. chalcographus or I. amitinus, respectively. Metapochonia bulbillosa was detected in I. typographus and P. chalcographus. This fungus is reported from the bark beetle hosts for the first time.

Table 3 List of species of entomopathogenic fungi identified from bark beetles in the Tatra National Park during 2014-2015.

\begin{tabular}{|c|c|c|c|}
\hline Bark beetle species & Fungal species & Name of collection site* & $\begin{array}{c}\text { No. of fungal } \\
\text { isolates }\end{array}$ \\
\hline \multirow[t]{15}{*}{ Ips typographus } & \multirow[t]{11}{*}{ Beauveria bassiana } & Podbanské I (3) & 16 \\
\hline & & Štrbské Pleso I (8) & 10 \\
\hline & & Podbanské II (2) & 2 \\
\hline & & Štrbské Pleso II (7) & 4 \\
\hline & & Vyšné Hágy II (10) & 24 \\
\hline & & Vyšné Hágy I (9) & 3 \\
\hline & & Štrbské Pleso III (6) & 2 \\
\hline & & Popradské Pleso (5) & 1 \\
\hline & & Vodopád Skok (4) & 3 \\
\hline & & Tatranská Lomnica II (13) & 19 \\
\hline & & Tatranská Lomnica I (12) & 6 \\
\hline & \multirow[t]{2}{*}{ Beauveria caledonica } & Krivánska cesta (1) & 1 \\
\hline & & Tatranská Lomnica II (13) & 3 \\
\hline & \multirow{2}{*}{ Metapochonia bulbillosa } & Tatranská Lomnica II (13) & 1 \\
\hline & & Vyšné Hágy (10) & 1 \\
\hline \multirow[t]{4}{*}{ Ips amitinus } & \multirow[t]{3}{*}{ Beauveria bassiana } & Štrbské Pleso I (8) & 2 \\
\hline & & Vyšné Hágy II (10) & 7 \\
\hline & & Tatranská Lomnica II (13) & 1 \\
\hline & Beauveria pseudobassiana & Vyšné Hágy II (10) & 1 \\
\hline \multirow{10}{*}{$\begin{array}{l}\text { Pityogenes } \\
\text { chalcographus }\end{array}$} & \multirow[t]{8}{*}{ Beauveria bassiana } & Podbanské I (3) & 1 \\
\hline & & Štrbské Pleso I (8) & 2 \\
\hline & & Štrbské Pleso II (7) & 1 \\
\hline & & Vyšné Hágy II (10) & 2 \\
\hline & & Popradské Pleso (5) & 1 \\
\hline & & Tatranská Lomnica II (13) & 2 \\
\hline & & Podspády - Krupovky (14) & 1 \\
\hline & & Podspády - Vojtašová (15) & 1 \\
\hline & Beauveria caledonica & Podspády - Vojtašová (15) & 1 \\
\hline & Metapochonia bulbillosa & Vyšné Hágy II (10) & 1 \\
\hline
\end{tabular}

*Numbers in the parenthesis represents the particular collection sites as displayed in Figure 1. 
Dataset for phylogenetic analysis included 43 sequences (Table 1): six sequences of representative isolates from this survey, 36 sequences of Beauveria species or M. bulbillosa from other studies and a sequence of Metarhizium anisopliae (strain ARSEF 7487) designated as the outgroup. The final dataset of sequences consisted of $22852 \mathrm{bp}$ and ML analysis produced a consensus tree (Figure 2) with a log-likelihood of -1720.18 . In the phylogenetic tree, the isolates of $B$. pseudobassiana, $B$. caledonica and $M$. bulbillosa each represented a single phylogenetic clade with the sequences of particular species. The $B$. bassiana isolates were clustered together with the neotype strain of $B$. bassiana (ARSEF 1564), however the clade comprises three distinct sub-clades. Almost $95 \%(n=105)$ of $B$. bassiana isolates obtained in this study are organised in the phylogenetic group A1 (Table 4).

Table 4 Phylogenetic classification of fungal isolates obtained from bark beetles in spruce forests of the Tatra National Park during 2014-2015.

\begin{tabular}{lccl}
\hline Fungal species & $\begin{array}{c}\text { Phylogenetic } \\
\text { group }\end{array}$ & $\begin{array}{c}\text { Number of } \\
\text { isolates }\end{array}$ & $\begin{array}{c}\text { GenBank Accession numbers of sequences } \\
\text { from this study* }\end{array}$ \\
\hline Beauveria bassiana & A1 & 105 & $\begin{array}{l}\text { MW051915-MW051928, MW051929- } \\
\text { MW051951, MW051953-MW051975, } \\
\end{array}$ \\
& & & $\begin{array}{l}\text { MW051977-MW051978, MW051980, } \\
\text { MW051982-MW052010, MW052012- }\end{array}$ \\
& A2 & 4 & $\begin{array}{l}\text { MW052015, MW052017-MW052019 } \\
\text { MW052016 , MW051979, MW052011, }\end{array}$ \\
Beauveria pseudobassiana & B & & MW051976, MW051981 \\
Beauveria caledonica & C & 2 & $\begin{array}{l}\text { MW052020, MW052021 } \\
\text { Metapochonia bulbillosa }\end{array}$ \\
\hline
\end{tabular}

*the GenBank Accession numbers highlighted in the bold type were selected for the phylogenetic analysis (Figure 2).

\section{Prevalence of fungal infection in populations of Ips typographus}

The prevalence of fungal infection in natural populations of I. typographus was low in the study area (Table 5). The mean percentage of galleries with infected individuals varied between 0.07 and $0.72 \%$ depending on the collection sites, but there was not significant difference in prevalence of fungal infection among the collection sites $\left(F_{(8,61)}=2.402\right.$; $p>0.05$ ). The mean infestation level of spruce logs by bark beetles varied significantly among collection sites $\left(F_{(8,61)}=12.443 ; p<0.05\right)$. The mean number of infected individuals per $1-\mathrm{m}^{2}$ area of debarked spruce logs reached 0.663.87 beetles and did not correlate $(r=-0.325$; $p=0.393$ ) with the total number of galleries per $1-\mathrm{m}^{2}$ area. For example, the highest disease prevalence $\left(0.72 \%\right.$ resp. 3.87 ind. $\left./ \mathrm{m}^{2}\right)$ was detected in the collection site (Podbanské I) with the lowest infestation of logs (5 164 galleries $/ \mathrm{m}^{2}$ ). The lowest fungal prevalence $\left(0.07 \%\right.$ resp. 0.66 ind. $\left.\mathrm{m}^{2}\right)$ was observed in the site (Tatranská Lomnica I) with low infestation (6 434 galleries $/ \mathrm{m}^{2}$ ) but, in contrast, in the site (Podbanské II) with the highest infestation by I. typographus (24 624 galleries $/ \mathrm{m}^{2}$ ) a moderate fungal prevalence $\left(0.10 \%\right.$ resp. 1.17 ind. $\left./ \mathrm{m}^{2}\right)$ was detected. 


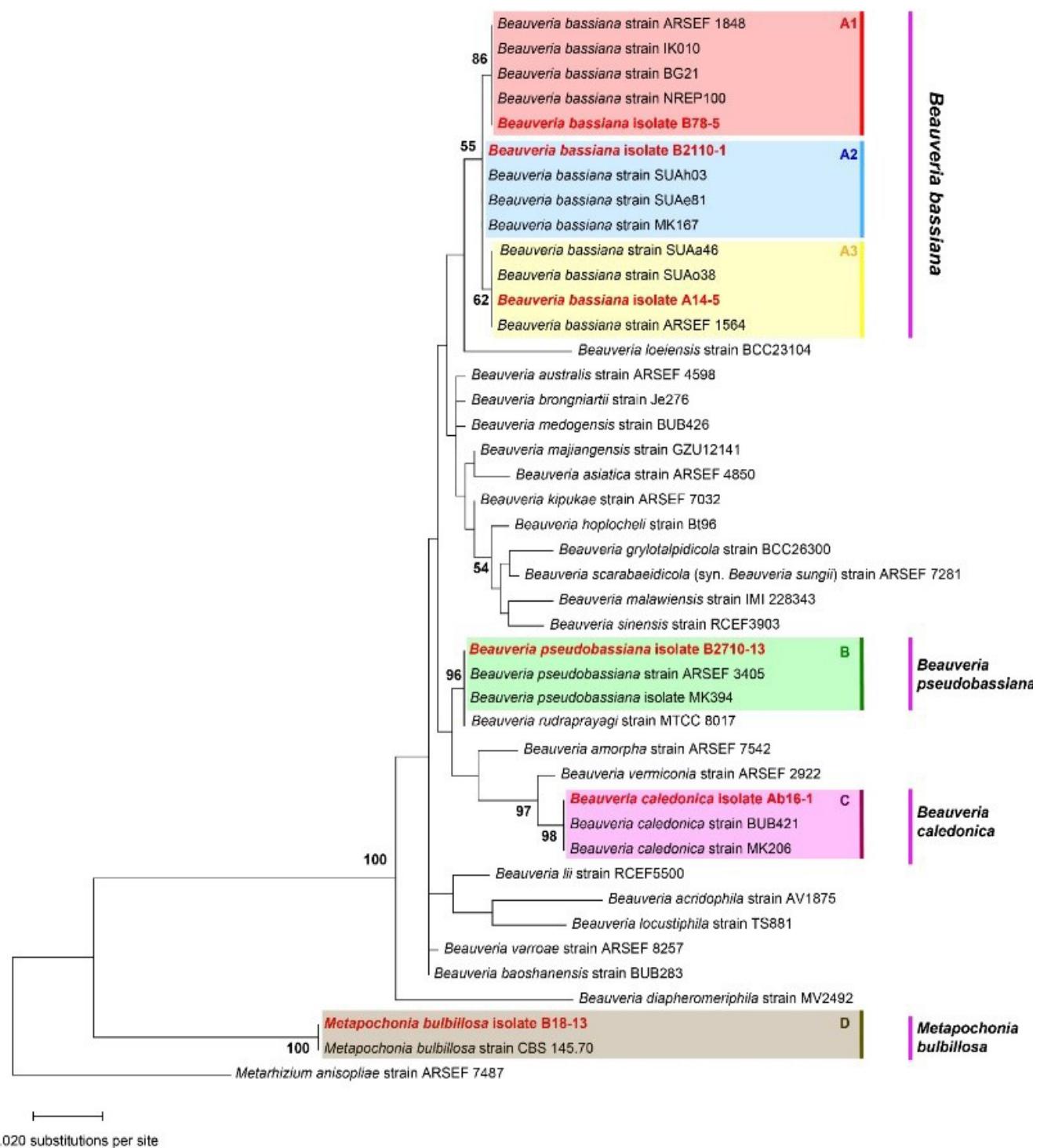

Figure 2 Phylogenetic tree showing relationships of isolates of entomopathogenic fungi inferred by using the maximum likelihood method and Tamura-Nei model (Tamura \& Nei 1993), tree with the highest log-likelihood (-1720.18) is shown, percentage of trees $(>50 \%)$ in which the associated taxa clustered together is shown next to the branches, Metarhizium anisopliae was used as outgroup, isolates collected and sequenced in this study are shown in red colour and bold type. 
Table 5 Infestation of spruce tree logs by Ips typographus with prevalence of fungal infection in the population in sites of the Tatra National Park during May-October 2016.

\begin{tabular}{|c|c|c|c|}
\hline Collection site* & $\begin{array}{l}\text { TNG per } 1 \text { m}^{2} \\
\text { mean } \pm \mathrm{SE}^{* *}\end{array}$ & $\begin{array}{c}\text { NGI per } 1 \text { m}^{2} \\
\text { mean } \pm \mathrm{SE}\end{array}$ & $\begin{array}{c}\mathrm{IP}(\%)^{* *} \\
\text { mean } \pm \mathrm{SE}\end{array}$ \\
\hline Podbanské I (1) & $5164.52 \pm 237.22 \mathrm{a}$ & $3.87 \pm 0.46$ & $0.72 \pm 0.15 \mathrm{a}$ \\
\hline Podbanské II (16) & $24624.83 \pm 6115.23 b$ & $1.17 \pm 0.51$ & $0.10 \pm 0.07 \mathrm{a}$ \\
\hline Podbanské III (17) & $7581.67 \pm 896.42 \mathrm{a}$ & $0.98 \pm 0.40$ & $0.08 \pm 0.03 a$ \\
\hline Vyšné Hágy I (9) & $7862.84 \pm 714.88 \mathrm{a}$ & $1.38 \pm 0.37$ & $0.09 \pm 0.02 \mathrm{a}$ \\
\hline Vyšné Hágy II (10) & $9490.70 \pm 1576.27 \mathrm{a}$ & $0.94 \pm 0.49$ & $0.09 \pm 0.05 \mathrm{a}$ \\
\hline Javorová dolina (18) & $6349.42 \pm 354.37 \mathrm{a}$ & $1.40 \pm 0.22$ & $0.14 \pm 0.03 a$ \\
\hline Podspády - Krupovky (14) & $9485.58 \pm 765.15 \mathrm{a}$ & $1.60 \pm 0.65$ & $0.11 \pm 0.04 \mathrm{a}$ \\
\hline Tatranská Lomnica I (12) & $6434.86 \pm 828.74 \mathrm{a}$ & $0.66 \pm 0.34$ & $0.07 \pm 0.09 \mathrm{a}$ \\
\hline Tatranská Lomnica II (13) & $5660.32 \pm 866.56 \mathrm{a}$ & $3.10 \pm 1.93$ & $0.36 \pm 0.17 \mathrm{a}$ \\
\hline Mean for all sites & $9183.86 \pm 571.17$ & $1.68 \pm 0.29$ & $0.20 \pm 0.05$ \\
\hline
\end{tabular}

*Numbers in the parenthesis refer to the particular collection sites as displayed in Figure 1.

**Means in the columns followed by the same letter are not significantly different (Tukey's HSD test, $p=0.05$ )

TNG - total number of larval galleries

NGI - number of larval galleries with infected individuals

IP - infection prevalence in population

\section{Discussion and conclusion}

\section{Species spectrum of entomopathogenic fungi in bark beetle populations}

During the past two decades the occurrence of EPF in bark beetle populations has been documented in Europe in several studies (e.g. Landa et al. 2001, Kreutzet al. 2004, Wegensteiner 2007, Draganova et al. 2010, Takov et al. 2012, Mudrončeková et al. 2013, Wegensteiner et al. 2015a, Barta et al. 2018a, 2020) and Beauveria species have been reported as common pathogens. The current study also demonstrates that infection by Beauveria is a natural mortality factor of bark beetles and the species composition of EPF in the Tatra National Park is similar to those reported from other European countries. The exception is the record of M. bulbillosa in this study. This species was originally described as Verticillium cephalosporum W. Gams and isolated from the tissue of spruce roots in Denmark (Gams 1971). Later, it was renamed to Verticillium bulbillosum W. Gams \& Malla (Gams 1988) and Pochonia bulbillosa (W. Gams \& Malla) Zare \& W. Gams
(Zare et al. 2001). In a recent phylogenetic study of anamorphic insect-pathogenic fungi linked to the sexual state Metacordyceps, a new genus Metapochonia was described for species of verticillium-like morphology and seven species, with M. bulbillosa, were included in the genus (Kepler et al. 2014). Although M. bulbillosa has not been reported from bark beetles or other insect hosts before, its former synonym $V$. bulbillosum was rarely recorded as a parasite of cyst nematodes (Heterodera sp.) (Dackman \& Nordbring-Hertz 1985). In 2014, M. bulbillosa was identified from soil samples and unidentified heteropteran hosts in Slovakia (Medo, personal communication, November 2020).

The Beauveria genus includes globally distributed species pathogenic to a broad range of insect hosts from many orders including Blattodea, Coleoptera, Diptera, Embioptera, Hemiptera, Hymenoptera, Lepidoptera, Mantodea, Neuroptera, Orthoptera, Phasmatodea, Siphonaptera and Thysanoptera (e.g. Zimmermann 2007, Rehner et al. 2011, Chen et al. 2017, Kepler et al. 2017, Khonsanit et al. 2020). Until now, as many as 24 species of the genus have been recognised and 14 of them 
have been reported as parasites of coleopterans (e.g. Rehner et al. 2011, Kepler et al. 2017, Chen et al. 2018, Bustamante et al. 2019, Khonsanit et al. 2020). Five species, including $B$. bassiana, $B$. brongniartii (Sacc.) Petch, B. caledonica, $B$. pseudobassiana and B. varroae S. A. Rehner \& R. A. Humber, have been recorded in Europe. While $B$. bassiana, B. brongniartii and $B$. pseudobassiana are cosmopolitan species infecting insect hosts living in various habitats, $B$. caledonica is originally known from the soil in Scotland (Bissett \& Widden 1988), but recently it was also reported from weevils (Curculionidae, Scolytinae) in New Zealand and Ireland (Glare et al. 2008) as well as from $I$. typographus in Slovakia (Barta et al. 2018a) and Bulgaria (Barta et al. 2020). Beauveria varroae was formerly known from ectoparasitic mites of honeybee in France, but recently it was also identified from coleopterans (Rehner et al. 2011) and lepidopteran pupae (Barta et al. 2020). Of the five Beauveria species known in Europe, four have been recorded in bark beetle populations. They are $B$. bassiana, B. caledonica, $B$. pseudobassiana and B. brongniartii (e.g. Landa et al. 2001, Wegensteiner 2007, Draganova et al. 2010, Takov et al. 2012, Mudrončeková et al. 2013, Wegensteiner et al. 2015a, Barta et al. 2018a, 2020). In the current survey, we recorded all of them except for $B$. brongniartii, which is a well-known parasite of coleopteran larvae living in soil (Zimmermann 2007). Recently, this species was reported from I. typographus in Bulgaria, but the identification was based on morphotaxonomic analysis and no detailed morphological characteristics were provided (Takov et al. 2012) or the morphological description was only limited to conidia (Draganova et al. 2010). Beauveria bassiana and $B$. brongniartii are morphologically very similar and all identifications supported by just a microscopic investigation must be judged with a caution. Generally, the identification of Beauveria species, especially in the anamorphic state, is rather problematic due to the structural simplicity and overlap in morphological characteristics. Thus, DNA barcoding is becoming the standard approach for species determination. For example, recent phylogenetic studies based on multilocus analyses revealed that $B$. brongniartii and $B$. bassiana include cryptic lineages and new species were described (Rehner \& Buckley 2005, Rehner et al. 2011). Beauveria bassiana belongs among the most frequently reported Beauveria species in natural populations of I. typographus in Europe (e.g. Landa et al. 2001, Takov et al. 2007, 2012, Wegensteiner 2007, Wegensteiner et al. 2015a, Barta et al. 2018a, 2020) and it also prevailed in the populations studied in the current survey. Although we identified B. pseudobassiana only in two individuals of bark beetles, in previous study this fungus was reported a common pathogen of bark beetles in Slovakia (Barta et al. 2018a). In laboratory bioassays, a high virulence against bark beetles was reported by this fungus and it was recommended as a perspective biocontrol agent of these pests (Kocaçevik et al. 2016). It also seems that $B$. pseudobassiana is adapted to a forest ecosystem since it was recognised to prefer forests to agricultural or meadow habitats (Medo et al. 2016).

\section{Prevalence of fungal infection in populations of Ips typographus}

The prevalence of fungal infection in natural populations of $I$. typographus was low and corresponds to results of similar studies in Europe (Draganova et al. 2010, Takov et al. 2012, Barta et al. 2018a, 2020). The observations of this study indicate that the fungal infection had no capacity to significantly influence populations of $I$. typographus during the massive outbreak. Biotic and abiotic factors that could contribute to the efficacy of entomopathogenic fungi in regulating eruptive forest insects like bark beetles have been recently analysed. Besides general abiotic factors that limit the efficacy of the fungi like temperature and ultraviolet light, biotic factors specific to the bark beetle environment like the existence of associated microorganisms, plant 
secondary metabolites and bark beetle behaviour have been discussed (Mann \& Thomas 2021). The transmission of fungal infection within and among populations occurs by direct contact between infected dead insects and susceptible hosts or indirectly via airborne spores or spores deposited on the plant surface or soil particles. We found no significant relationship between host density and infection cases in the analysed populations. Due to a cryptic behaviour of bark beetles during a significant part of their life cycle, the factor of host density is probably not crucial for disease spreading. Several other studies confirm that this group of EPF is usually associated with bark beetle populations at low but constant prevalence level (Takov et al. 2006, 2007, 2012, Draganova et al. 2010, Barta et al. 2018a, 2020) and natural epizootics do not occur in host populations. From the viewpoint of bark beetle outbreak management, our observations indicate that a simple reliance on the natural activity of entomopathogenic fungi would not reduce the bark beetle abundance. Therefore, there have been numerous efforts for developing of effective augmentation techniques for introduction of fungal inoculum into bark beetle populations (e.g. Kreutz et al. 2004, Grégoire \& Evans 2007, Vakula et al. 2012, Barta et al. 2018 b). Especially in protected forests, where the standard management practices are not allowed, an efficient method of Beauveria spores augmentation would be valuable (Barta et al. 2018b).

In the phylogenetic tree, all fungal species identified from the bark beetles were clustered with the type strains of corresponding species. The Slovak isolate of M. bulbillosa is clustered together with the type strain CBS 145.70 (Zare et al. 2001). Beauveria caledonica isolate from this survey is grouped into one strongly supported clade together with the type strain ARSEF 2567 (Rehner et al. 2011) as well as the strain MK206 (Barta et al. 2018a) also isolated from I. typographus in Slovakia. All B. pseudobassiana sequences are clustered together with the type strain ARSEF 3405 (Rehner et al.
2011). However, the type strain MTCC 8017 of B. rudraprayagi (Agrawal et al. 2014) is also placed in this clade. Beauveria rudraprayagi was originally described from a silkworm in India through a multi-gene phylogenetic analysis. It could not be distinguished from $B$. pseudobassiana ( $98 \%$ bootstrap support) by ITSbased analysis as mentioned in the original report (Agrawal et al. 2014), what is also documented by the phylogenetic tree of this study. Beauveria bassiana sequences of the Slovak isolates are clustered together, however, the clade comprises three distinct sub-clades. All the $B$. bassiana sub-clades were previously reported in isolates from soil or insect hosts in Europe (Meyling et al. 2009, 2012). The majority of B. bassiana isolates from this study are organised in the phylogenetic group A1. This group corresponds to the group Eu4 reported for isolates from soil or insect hosts in Denmark (Meyling et al. 2009, 2012) and interestingly, it was not detected from the soil during the extensive survey conducted in Slovakia in 2008 (Medo et al. 2016). Four $B$. bassiana isolates are placed in the group A2 that was previously identified as the group Eu6 by Meyling et al. (2009, 2012). Two B. bassiana isolates are placed in the phylogenetic group A3 that corresponds to the group Eu1 (Meyling et al. 2009, 2012). This phylogenetic group of $B$. bassiana was considered the most common in agricultural soil in recent studies (Medo et al. 2016, Meyling et al. 2009). Genetic variability of B. bassiana isolates obtained from bark beetles was lower than the variability of isolates obtained from soils in Denmark and Slovakia (Medo et al. 2016, Meyling et al. 2009). The ITS region, which was used in this study, is considered a universal barcode for fungi and is widely used in taxonomic analysis, however the application of multiple gene regions can significantly enhance the taxonomic resolution at inter-species level (Rehner et al. 2011). For example, eight genetic lineages comprising 15 haplotypes were detected in soil samples from Slovakia, when two DNA loci (ITS and Bloc regions) were analysed (Medo et al. 2016, 2021). 


\section{Conclusions}

The survey on the occurrence of entomopathogenic fungi in populations of bark beetles in the Tatra National Park revealed activity of four fungal species, $B$. bassiana, B. pseudobassiana, B. caledonica and M. bulbillosa. Beauveria bassiana was the dominant pathogen infecting three bark beetle species, in particular I. typographus, I. amitinus and P. chalcographus. Fungal infection in populations of $I$. amitinus and $P$. chalcographus is reported for the first time in Slovakia. Metapochonia bulbillosa, the fungus originally isolated from the tissue of spruce roots or reported as an occasional parasite of cyst nematodes, was detected from bark beetles for the first time. Phylogenetic analysis identified three genetic lineages in population of $B$. bassiana parasitising bark beetles in the Tatra National Park, but the majority of analysed isolates were placed in a single phylogenetic group. The low natural prevalence of infected individuals during the population outbreaks indicates that Beauveria infection does not have sufficient capacity to regulate bark beetle abundances. Therefore, from the practical perspective, a searching for effective augmentation techniques how to release Beauveria inoculum into bark beetle populations is necessary.

\section{Acknowledgement}

The work was supported by the Slovak research and development agency, grants no. APVV-16-0031 and APVV-19-0116.

\section{References}

Agrawal Y., Mual P., Shenoy B.D., 2014. Multigene genealogies reveal cryptic species Beauveria rudraprayagi sp. nov. from India. Mycosphere 5(6): 719-736. https://doi.org/10.5943/mycosphere/5/6/3

Ariyawansa H.A., Hyde K.D., Jayasiri S.C., Buyck B., Chethana K.W.T. et al., 2015. Fungal diversity notes 111-252-taxonomic and phylogenetic contributions to fungal taxa. Fungal Divers 75(1): 27-274. https://doi. org/10.1007/s13225-015-0346-5

Augustyniuk-Kram A., Kram K.J., 2012. Entomopathogenic fungi as an important natural regulator of insect outbreaks in forests (Review). In Blanco J.A., Lo Y.H. (eds.), Forest Ecosystems - More than Just Trees. InTech, Rijeka, pp. 265-294.

Barta M., Kautmanová I., Čičková H., Ferenčík J., Florián Š., Novotný J., Kozánek M., 2018a. Hypocrealean fungi associated with populations of Ips typographus in West Carpathians and selection of local Beauveria strains for effective bark beetle control. Biologia 73(1): 53-65. https://doi.org/10.2478/s11756-018-0005-x

Barta M., Kautmanová I., Čičková H., Ferenčík J., Florián Š., Novotný J., Kozánek M., 2018b. The potential of Beauveria bassiana inoculum formulated into a polymeric matrix for a microbial control of spruce bark beetle. Biocontrol Science and Technology 28(7): 718735. https://doi.org/10.1080/09583157.2018.1487027

Barta M., Lalík M., Rel S., Kunca A., Horáková M. K., Mudrončeková S., Galko J., 2019. Hypocrealean fungi associated with Hylobius abietis in Slovakia, their virulence against weevil adults and effect on feeding damage in laboratory. Forests 10(8): 634. https://doi. org/10.3390/f10080634

Barta M., Takov D., Pilarska D., Doychev D., Horáková M. K., 2020. Entomopathogenic fungi of the genus Beauveria and their pathogenicity to Ips typographus (Coleoptera: Curculionidae) in the Vitosha National Park, Bulgaria. Journal of Forest Science 66(10): 420435. https://doi.org/10.17221/123/2020-JFS

Biedermann P.H., Müller J., Grégoire J.C., Gruppe A., Hagge J., Hammerbacher A., Hofstetter W., Kandasamy D., Kolarik M., Kostovcik M., Krokene P., Sallé A., Six D.L, Turrini T., Vanderpool D., Wingfield M.J., Bässler C., 2019. Bark beetle population dynamics in the Anthropocene: challenges and solutions. Trends in Ecology \& Evolution 34(10): 914-924. https://doi. org/10.1016/j.tree.2019.06.002

Bisset J., Widden P., 1988. A new species of Beauveria isolated from Scottish moorland soil. Canadian Journal of Botany 66: 361-362.

Bustamante D.E., Oliva M., Leiva S., Mendoza J.E., Bobadilla L., Angulo G., Calderon M.S., 2019. Phylogeny and species delimitations in the entomopathogenic genus Beauveria (Hypocreales, Ascomycota), including the description of $B$. peruviensis sp. nov. MycoKeys 58: 47-68. https://doi. org/10.3897/mycokeys.58.35764

Cognato A.I., 2015. Biology, systematics, and evolution of Ips. In Vega F.E., Hofstetter R.W. (eds.), Bark beetles: biology and ecology of native and invasive species. Elsevier, San Diego, CA, pp. 351-370. https://doi. org/10.1016/B978-0-12-417156-5.00009-5

Chen M.J., Huang B., Li Z.Z., Spatafora J.W., 2013. Morphological and genetic characterisation of Beauveria sinensis sp. nov. from China. Mycotaxon 124: 301-308. https://doi.org/10.5248/124.301 
Chen W.H., Han Y.F., Liang Z.Q., Jin D.C., 2017. A new araneogenous fungus in the genus Beauveria from Guizhou, China. Phytotaxa 302(1): 57-64. https://doi. org/10.11646/phytotaxa.302.1.5

Chen W.H., Liu M., Huang Z.X., Yang G.M., Han Y.F., Liang J.D., Liang Z.Q., 2018. Beauveria majiangensis, a new entomopathogenic fungus from Guizhou, China. Phytotaxa 333(2): 243-250. https://doi.org/10.11646/ phytotaxa.333.2.8

Chen Z.H., Chen K., Dai Y.D., Zheng Y., Wang Y.B., Yang X.N., Yu H., Yang Y.M., Xu, L., 2019. Beauveria species diversity in the Gaoligong Mountains of China. Mycological Progress 18(7): 933-943. https://doi. org/10.1007/s11557-019-01497-z

Dackman C., Nordbring-Hertz B., 1985. Fungal parasites of the cereal cyst nematode Heterodera avenae in Southern Sweden. Journal of Nematology 17(1): 50-55.

Draganova S., Takov D., Doychev D., 2010. Naturallyoccurring entomopathogenic fungi on three bark beetle species (Coleoptera: Curculionidae) in Bulgaria. Pesticides \& Phytomedicine (Belgrade) 25(1): 59-63. https://doi.org/10.2298/PIF1001059D

Dinu M. M., Lupăştean D., Cardaş G., Andrei A. M., 2012. New Beauveria bassiana (Bals). Vuill. isolate from Ips duplicatus (Sahlberg). Romanian Journal of Plant Protection 5: 12-15.

Edgar R.C., 2004. Muscle: multiple sequence alignment with high accuracy and high throughput. Nucleic Acids Research (32): 1792-1797. https://doi.org/10.1093/nar/ gkh340

Falt’an V., Bánovský M., Blažek M., 2011. Evaluation of land cover changes after extraordinary windstorm by using the land cover metrics: A case study on the High Tatras foothill. Geografie 116(2): 156-171. https://doi. org/10.37040/geografie2011116020156

Ferenčík J., 2016. Lykožrút smrekový vo Vysokých Tatrách [European spruce bark beetle in Tatra Mts]. Holušová K. (ed), Karpatské lesy conference, 4-5 May 2016, Bunč. Forest Management Institute, Brandýs nad Labem, pp. 101-114.

Fleischer P., Godzik B., Bicarova S., BytnerowiczA., 2005. Effects of air pollution and climate change on forests of the Tatra Mountains, Central Europe. In Omasa K., Nouchi I., De Kok L.J. (eds.), Plant Responses to Air Pollution and Global Change. Springer, Tokyo, pp. 111121. https://doi.org/10.1007/4-431-31014-2 13

Fleischer P. jr., Fleischer P., Ferenčík J., Hlaváč P., Kozánek M., 2016. Elevated bark temperature in unremoved stumps after disturbances facilitates multi-voltinism in Ips typographus population in a mountainous forest. Forestry Journal 62(1): 15-22. https://doi.org/10.1515/ forj-2016-0002

Fora C.G., Banu C.M., Chisăliţă I., Moatăr M.M., Oltean I., 2014. Parasitoids and predators of Ips typographus (L.) in unmanaged and managed spruce forests in Natural Park Apuseni, Romania. Notulae Botanicae Horti Agrobotanici Cluj-Napoca 42(1): 270-274. https://doi.org/10.15835/nbha4219430
Gams W., 1971. Cephalosporium-artige Schimmelpilze (Hyphomycetes). Gustav Fischer Verlag, Stuttgart, 262 p.

Gams W., 1988. A contribution to the knowledge of nematophagous species of Verticillium. Netherlands Journal of Plant Pathology 94(3): 123-148.

Glare T.R., Reay S.D., Nelson T.L., Moore R., 2008. Beauveria caledonica is a naturally occurring pathogen of forest beetles. Mycological Research 112(3): 352360. https://doi.org/10.1016/j.mycres.2007.10.015

Grégoire, J. C., Evans, H. F., 2007. Damage and control of BAWBILT organisms an overview. In Lieutier, F. et al. (eds.), Bark and wood boring insects in living trees in Europe, a synthesis. Springer, Dordrecht, pp. 19-37. https://doi.org/10.1007/978-1-4020-2241-8 4

Grodzki W., McManus M., Knížek M., Meshkova V., Mihalciuc V., Novotny J., Turčáni M., Slobodyan Y., 2004. Occurrence of spruce bark beetles in forest stands at different levels of air pollution stress. Environmental Pollution 130(1): 73-83. https://doi.org/10.1016/j. envpol.2003.10.022

Grodzki W., Turčáni M., Jakuš R., Hlásny T., Raši R., McManus M.L., 2010. Bark beetles in the Tatra Mountains. International research 1998-2005 - an overview. Folia Forestalia Polonica, Series A 52(2): 114-130. https://doi.org/10.5281/zenodo.30733

Hilszczański J., Gibb H., Bystrowski C., 2007. Insect natural enemies of Ips typographus (L). (Coleoptera, Scolytinae) in managed and unmanaged stands of mixed lowland forest in Poland. Journal of Pest Science 80(2): 99-107. https://doi.org/10.1007/s10340-006-0160-7

Hlásny T., Zimová S., Merganičová K., Štěpánek P., Modlinger R., Turčáni, M. 2021. Devastating outbreak of bark beetles in the Czech Republic: Drivers, impacts, and management implications. Forest Ecology and Management, 490, 119075. https://doi.org/10.1016/j. foreco.2021.119075

Humber R.A., 2012. Identification of entomopathogenic fungi. In Lacey L.A. (ed.), Manual of techniques in invertebrate pathology. Academic Press, Amsterdam, pp. 151-187.

Jakoby O., Lischke H., Wermelinger B., 2019. Climate change alters elevational phenology patterns of the European spruce bark beetle (Ips typographus). Global Change Biology 25: 4048-4063. https://doi. org/10.1111/gcb. 14766

Kautz M., Dworschak K., Gruppe A., Schopf R., 2011. Quantifying spatio-temporal dispersion of bark beetle infestations in epidemic and non-epidemic conditions. Forest Ecology and Management 262(4): 598-608. https://doi.org/10.1016/j.foreco.2011.04.023

Kepler R.M., Humber R.A., Bischoff J.F., Rehner S.A., 2014. Clarification of generic and species boundaries for Metarhizium and related fungi through multigene phylogenetics. Mycologia 106(4): 811-829. https://doi. org/10.3852/13-319

Kepler R.M., Luangsa-ard J.J., Hywel-Jones N.L., Quandt C.A., Sung G.H., Rehner S.A., Aime M.C., Henkel T.W., Sanjuan T., Zare R., Chen M.J., Li Z.Z., Rossman A.Y., 
Spatafora J.W., Shrestha B., 2017. A phylogeneticallybased nomenclature for Cordycipitaceae (Hypocreales). IMA Fungus 8(2): 335-353. https://doi.org/10.5598/ imafungus.2017.08.02.08

Khonsanit A., Luangsa-ard J.J., Thanakitpipattana D., Noisripoom W., Chaitika T., Kobmoo N., 2020. Cryptic diversity of the genus Beauveria with a new species from Thailand. Mycological Progress 19(4): 291-315. https://doi.org/10.1007/s11557-020-01557-9

Kocaçevik S., Sevim A., Eroğlu M., Demirbağ Z., Demir I., 2016. Virulence and horizontal transmission of Beauveria pseudobassiana S.A. Rehner \& Humber in Ips sexdentatus and Ips typographus (Coleoptera: Curculionidae). Turkish Journal of Agriculture and Forestry 40(2): 241-248. https://doi.org/10.3906/tar1504-64

Knížek M., Beaver R., 2007. Taxonomy and systematics of bark and ambrosia beetles. In Lieutier F. et al. (eds.), Bark and wood boring insects in living trees in Europe, a synthesis. Springer, Dordrecht, pp. 41-54. https://doi. org/10.1007/978-1-4020-2241-8 5

Kreutz J., Vaupel O., Zimmermann G., 2004. Efficacy of Beauveria bassiana (Bals.) Vuill. against the spruce bark beetle, Ips typographus L., in the laboratory under various conditions. Journal of Applied Entomology 128(6): 384-389. https://doi.org/10.1111/j.14390418.2004.00813.x

Kumar S., Stecher G., Li M., Knyaz C., Tamura K., 2018. MEGA X: Molecular evolutionary genetics analysis across computing platforms. Molecular Biology and Evolution 35(6): 1547-1549. https://doi.org/10.1093/ molbev/msy096

Kunca A., Zúbrik M., 2006. Vetrová kalamita z 19. 11. 2004 [Wind calamity on November 19, 2004]. National Forest Centre, Zvolen, $40 \mathrm{p}$.

Landa Z., Horňák P., Osborne L.S., Nováková A., Bursová E., 2001. Entomogenous fungi associated with spruce bark beetle Ips typographus L. (Coleoptera, Scolytidae) in the Bohemian Forest. Silva Gabreta 6: 259-272.

Mann A.J., Davis T.S., 2021. Entomopathogenic fungi to control bark beetles: a review of ecological recommendations. Pest Management Science. https:// doi.org/10.1002/ps.6364.

Medo J., Michalko J., Medová J., Cagáň L., 2016. Phylogenetic structure and habitat associations of Beauveria species isolated from soils in Slovakia. Journal of Invertebrate Pathology 140: 46-50. https:// doi.org/10.1016/j.jip.2016.08.009

Medo J., Medová J., Michalko J., Cagán̆ L., 2021. Variability in virulence of Beauveria spp. soil isolates against Ostrinia nubilalis. Journal of Applied Entomology 145(1-2): 92-103. https://doi.org/10.1111/ jen. 12806

Meyling N.V., Lübeck M., Buckley E.P., Eilenberg J., Rehner S.A., 2009. Community composition, host range and genetic structure of the fungal entomopathogen Beauveria in adjoining agricultural and seminatural habitats. Molecular Ecology 18(6): 1282-1293. https://
doi.org/10.1111/j.1365-294X.2009.04095.X

Meyling N.V., Pilz C., Keller S., Widmer F., Enkerli J., 2012. Diversity of Beauveria spp. isolates from pollen beetles Meligethes aeneus in Switzerland. Journal of Invertebrate Pathology 109(1): 76-82. https://doi. org/10.1016/j.jip.2011.10.001

Mudrončeková S., Mazán M., Nemcovic M., Salamon I., 2013. Entomopathogenic fungus species Beauveria bassiana (Bals.) and Metarhizium anisopliae (Metsch.) used as mycoinsecticide effective in biological control of Ips typographus (L.). The Journal of Microbiology, Biotechnology and Food Sciences 2(6): 2469-2472.

Niedzwiedz T., 1992. Climate of the Tatra Mountains. Mountain Research and Development 12(2): 131-146.

Nopp U., Führer E. 2000. Assessment of the predisposition of spruce-abundant forests to various disturbances. In Klimo E., Hager H., Kulhavý J. (eds.), Spruce Monocultures in Central Europe - Problems and Prospects. European Forest Institute, Joensuu, Finland, pp. 113-117.

Økland B., Bjørnstad O.N., 2006. A resource-depletion model of forest insect outbreaks. Ecology 87(2): 283290. https://doi.org/10.1890/05-0135

Økland B., Netherer S., Marini L., 2015. The Eurasian spruce bark beetle: The role of climate. In Björkman C., Niemelä P. (eds.), Climate change and insect pests. CABI, Wallingford, pp. 202-219. https://doi. org/10.1079/9781780643786.0202

Økland B., Nikolov C., Krokene P., Vakula J., 2016. Transition from windfall- to patch-driven outbreak dynamics of the spruce bark beetle Ips typographus. Forest Ecology and Management 363: 63-73. https:// doi.org/10.1016/j.foreco.2015.12.007

Rehner S.A., Buckley E.P., 2005. A Beauveria phylogeny inferred from ITS and EF1- $\alpha$ sequences: evidence for cryptic diversification and links to Cordyceps teleomorphs. Mycologia 97(1): 84-98. https://doi.org/1 $0.1080 / 15572536.2006 .11832842$

Rehner S.A., Posada F., Buckley E.P., Infante F., Castillo A., Vega F.E., 2006. Phylogenetic origins of African and Neotropical Beauveria bassiana s.l. pathogens of the coffee berry borer, Hypothenemus hampei. Journal of Invertebrate Pathology 93: 11-21. https://doi. org/10.1016/j.jip.2006.04.005

Rehner S.A., Minnis A.M., Sung G.H., Luangsa-ard J.J., Devotto L., Humber R.A., 2011. Phylogeny and systematics of the anamorphic, entomopathogenic genus Beauveria. Mycologia 103: 1055-1073. https:// doi.org/10.3852/10-302

Robène-Soustrade I., Jouen E., Pastou D., Payet-Hoarau M., Goble T., Linderme D., Lefeuvre P., Calmès C., Reynaud B., Nibouche S., Costet L., 2015. Description and phylogenetic placement of Beauveria hoplocheli sp. nov. used in the biological control of the sugarcane white grub, Hoplochelus marginalis, on Reunion Island. Mycologia 107: 1221-1232. https://doi.org/10.3852/14344 
Sanjuan T., Tabima J., Restrepo S., Læssøe T., Spatafora J.W., Franco-Molano A.E., 2014. Entomopathogens of Amazonian stick insects and locusts are members of the Beauveria species complex (Cordyceps sensu stricto). Mycologia 106(2): 260-275. https://doi. org/10.3852/106.2.260

Schneider S., Rehner S.A., Widmer F., Enkerli J., 2011. A PCR-based tool for cultivation-independent detection and quantification of Metarhizium clade 1. Journal of Invertebrate Pathology 108(2): 106-114. https://doi. org/10.1016/j.jip.2011.07.005

Seidl R., Müller J., Hothorn T., Bässler C., Heurich M., Kautz M., 2015. Small beetle, large-scale drivers: how regional and landscape factors affect outbreaks of the European spruce bark beetle. Journal of Applied Ecology 53(2): 530-540. https://doi.org/10.1111/13652664.12540

Stadelmann G., Bugmann H., Wermelinger B., Bigler C., 2014. Spatial interactions between storm damage and subsequent infestations by the European spruce bark beetle. Forest Ecology and Management 318: 167-174. https://doi.org/10.1016/j.foreco.2014.01.022

Takov D., Pilarska D., Wegensteiner R., 2006. Entomopathogens in Ips typographus (Coleoptera: Scolytidae) from several spruce stands in Bulgaria. Acta Zoologica Bulgarica 58(3): 409-420.

Takov D., Doychev D., Wegensteiner R., Pilarska D., 2007. Study of bark beetle (Coleoptera, Scolytidae) pathogens from coniferous stands in Bulgaria. Acta Zoologica Bulgarica 59(1): 87-96.

Takov D., Doychev D., Linde A., Draganova S., Pilarska D., 2012. Pathogens of bark beetles (Curculionidae: Scolytinae) and other beetles in Bulgaria. Biologia 67: 966-972. https://doi.org/10.2478/s11756-012-0086-X

Tamura K., Nei M., 1993. Estimation of the number of nucleotide substitutions in the control region of mitochondrial DNA in humans and chimpanzees. Molecular Biology and Evolution 10(3): 512-526.

Turčáni M., Hlásny, T., 2007. Spatial distribution of four spruce bark beetles in North-Western Slovakia. Journal of Forest Science 53: 45-52. https://doi. org/10.17221/2157-JFS

Vakula J., Gubka A., Galko J., Varkonda Š. 2012. Aplikácia entomopatogénov do populácii škodcov $\mathrm{s}$ využitím feromónových lapačov. [Application of entomopathogens to pest populations using pheromone traps]. In Kunca A. (ed.), Aktuálne problémy v ochrane lesa. National Forest Centre, Zvolen, pp. 92-96.

Vakula J., Gubka A., Galko J., Kunca A., Zúbrik M., 2013. Podkôrny hmyz - pretrvávajúca hrozba smrečín Slovenska. Aké sú dôvody? [Bark beetles - the continuing threat of spruce forests of Slovakia. What are the reasons?] Les a Letokruhy 7-8: 38-39.

Vega F.E., Meyling N.V., Luangsa-Ard J.J., Blackwell M., 2012. Chapter 6 - Fungal Entomopathogens. In Vega F.E., Kaya H.K. (eds.), Insect Pathology. Academic Press, San Diego, pp. 171-220. https://doi.org/10.1016/ B978-0-12-384984-7.00006-3
Wegensteiner R., 2007. Pathogens in bark beetles. In Lieutier F., Day K.R., Battisti A., Grégoire J.C., Evans H.F. (eds), Bark and wood boring insects in living trees in Europe, a synthesis. Springer, Dordrecht, pp. 291313. https://doi.org/10.1007/978-1-4020-2241-8_12

Wegensteiner R., Dedryver C.A., Pierre J.S., 2010. The comparative prevalence and demographic impact of two pathogens in swarming Ips typographus adults: a quantitative analysis of long term trapping data. Agricultural and Forest Entomology 12(1): 49-57. https://doi.org/10.1111/j.1461-9563.2009.00449.x

Wegensteiner R., Tkaczuk C., Bałazy S., Griesser S., Rouffaud M.A., Stradner A., Steinwender B.M., Hager H., Papierok B., 2015a. Occurrence of pathogens in populations of Ips typographus, Ips sexdentatus (Coleoptera, Curculionidae, Scolytinae) and Hylobius spp. (Coleoptera, Curculionidae, Curculioninae) from Austria, Poland and France. Acta Protozoologica 54(3): 219-232. https://doi.org/10.4467/16890027 AP.15.018.3215

Wegensteiner R., Wermelinger B., Herrmann M., 2015 b. Natural enemies of bark beetles: predators, parasitoids, pathogens, and nematodes. In Vega F.E., Hofstetter R.W. (eds.), Bark beetles - biology and ecology of native and invasive species. Academic press, London, pp. 247-304. https://doi.org/10.1016/B978-0-12417156-5.00007-1

Wermelinger B., 2004. Ecology and management of the spruce bark beetle Ips typographus - a review of recent research. Forest ecology and management 202(1-3): 6782. https://doi.org/10.1016/j.foreco.2004.07.018

White T.J., Bruns T., Lee S., Taylor J., 1990. Amplification and direct sequencing of fungal ribosomal RNA genes for phylogenetics. In Innis M.A., Gelfand D.H., Sninsky J.J., White T.J., (eds.), PCR Protocols: A guide to methods and applications. Academic Press, pp. 315322.

Zare R., Gams W., Evans H.C., 2001. A revision of Verticillium section Prostrata. V. The genus Pochonia, with notes on Rotiferophthora. Nova Hedwigia 73(1-2): 51-86. https://doi.org/10.1127/nova. hedwigia/73/2001/51

Zhang S.L., He L.M., Chen X., Huang B., 2012. Beauveria lii sp. nov. isolated from Henosepilachna vigintioctopunctata. Mycotaxon 121(1): 199-206. https://doi.org/10.5248/121.199

Zimmermann G., 2007. Review on safety of the entomopathogenic fungi Beauveria bassiana and Beauveria brongniartii. Biocontrol Science and Technology 17(6): 553-596. https://doi. org/10.1080/09583150701309006 
